\title{
Ambush Marketing in China: Counterbalancing Olympic Sponsorship Efforts
}

\author{
Holger Preuss $^{\mathrm{a}}$, Kai Gemeinder ${ }^{\mathrm{a}}$ and Benoit Séguin ${ }^{\mathrm{b}}$ \\ ${ }^{a}$ Institute of Sport Science, Johannes Gutenberg-University, Saarstraße 21, Mainz 55099, \\ Germany. \\ E-mail: preuss@uni-mainz.de \\ ${ }^{\mathrm{b}}$ School of Human Kinetics, University of Ottawa, Ottawa, Canada.
}

This paper provides an empirical insight into the perception and use of ambush marketing on the People's Republic of China public television network CCTV5 (the official Olympic broadcaster), by examining the commercials used by various corporations during its coverage of the 2004 Olympic Games in Athens. A fivepoint categorization is presented to distinguish between various methods of ambushing. Despite the efforts of the Beijing government to fight ambush marketing ahead of its Olympic Games in 2008, the results demonstrate that concerns about the practice of ambush marketing in China must be taken seriously. An analysis of 40 commercial spots was carried out, based on China's 2002 Olympic Symbol Protection Law, as well as a comparison of ambush marketing on Chinese CCTV5 with nine other nations. This paper concludes with some theoretical considerations concerning general protection of Olympic sponsors and reflects on particular cultural backgrounds in China that may relate to ambush marketing.

Asian Business \& Management (2008) 7, 243-263. doi:10.1057/abm.2008.3

Keywords: ambush marketing; 2008 Beijing Olympic Games; China; sponsorship in China; Olympic brand protection; ambush marketing legislation

\section{Introduction}

The Olympic Games have experienced phenomenal growth over the past 30 years. Hosting the Olympics is now a complex and expensive undertaking requiring the support of the private sector:

'Without the support of the business community, without its technology, expertise, people, services, products, telecommunications, its financing the Olympic Games could not and cannot happen. Without this support, the athletes cannot compete and achieve their very best in the world's best 
sporting event'. (J. Rogge, http://www.olympic.org/uk/organisation/facts/ introduction/index_uk.asp; accd. 7 December 2007)

The revenues from TV broadcasting and other marketing rights (eg sponsorship) make up most of the finance sources of the Organising Committee for the Olympic Games (OCOG) and National Olympic Committees (NOCs). The International Olympic Committee (IOC) worldwide sponsorship programme (TOP) has increased income by 900 per cent over a 20 year period (Table 1). This suggests that the Olympics are a powerful brand with the ability to provide much benefit to commercial partners. Hence, it is not surprising that despite their exclusive worldwide rights, TOP sponsors are not the only companies seeking to create an association with the Olympic brand. In fact, many non-sponsors feel obliged to use this exclusive marketing platform in the hope of establishing some cognitive association with Olympic values (Séguin and O'Reilly, 2008). Such attempts are commonly known as 'ambush marketing'.

The main goals of ambush marketing are to gain some of the benefits of association with a 'mega' event (eg Olympic Games), while weakening the impact of an official sponsor (ie competitor) (Sandler and Shani, 1989). In other words, an association with a highly emotive and positively perceived event captures consumer attention while simultaneously causing 'cluttering', due to the increased number of corporations advertising with an Olympic theme as a platform (Séguin and O'Reilly, 2008). Cluttering causes 'noise' in the communication process (Shank, 2005), since a number of companies are fighting for the attention of consumers over specific messages and/or commercial activities. If uncontrolled, ambush marketing and cluttering may lead to a decrease in the willingness of sponsors, actual and potential, to acquire Olympic marketing rights. According to former IOC marketing director Michael Payne, cited by Meenaghan (1996: 108), 'ambush marketing has the potential to destroy sponsorship' and may ultimately jeopardize the financing of the Olympic Movement.

Table 1 Evolution of TOP programme

\begin{tabular}{lcccccr}
\hline & TOP I & TOP II & TOP III & TOP IV & TOP V & TOP VI \\
& $1985-1988$ & 1989-1992 & 1993-1996 & 1997-2000 & 2001-2004 & 2005-2008 \\
\hline Number of companies & 9 & 12 & 10 & 11 & 10 & 12 \\
Number of NOCs & 159 & 169 & 197 & 199 & 202 & 202 \\
$\begin{array}{l}\text { Revenue generated in } \\
\text { US Smillion }\end{array}$ & 96 & 172 & 279 & 579 & 663 & 866 \\
\hline
\end{tabular}

Sources: IOC (2006), Preuss (2004). 
The Olympic Games to be hosted in Beijing 2008 is the source of much attention worldwide. From a business standpoint, China's cultural environment poses some challenges in the planning and execution of a sponsorship programme such as TOP. For example, for Chinese, intellectual sharing is an integral part of their culture (Alford, 1995). Hence, for many Chinese corporations (sponsors or non-sponsors) it may seem perfectly legitimate to use the Games as a way to gain benefit. In a culture influenced by Confucius and communism, the inherent need to fiercely protect one's intellectual property may not be as strong as in Western Europe. Since plagiarism is a well-known phenomenon in the People's Republic of China (PRC) (Montgomery, 2004), the ability to effectively protect the Olympic brand and its marketing rights creates some strains on Chinese and IOC officials, despite efforts by the Chinese government to preserve brand integrity.

This paper will demonstrate that such concerns must be taken seriously. It will provide insights into the perception and use of ambush marketing on the Chinese public television network CCTV5 (the official Olympic broadcaster, for the Games in 2008 also) by examining the commercials used by various corporations during the coverage of the last Olympic Games, held in Athens in 2004. In total, 40 commercial spots are analysed by examining the type of messages and positioning of advertisements with regard to the Olympics (ie ambush marketing). A general categorization of Olympic ambush marketing for television is presented. Finally, we will describe two of these commercials as case studies.

\section{Overview of Ambush Marketing Literature}

A Wall Street Journal article entitled 'Ambush Marketing is becoming a popular event at Olympic Games', published in 1988, created the impetus for scientific research on ambush marketing. Sandler and Shani (1989: 11) published the first scientific article on the subject and defined ambush marketing as

a planned effort (campaign) by an organisation to associate themselves with an event in order to gain at least some of the recognition and benefits that are associated with being an official sponsor.

This first publication by Sandler and Shani launched a new line of research in the field of sports marketing. A number of publications on ambush marketing describe and analyse this marketing strategy (Sandler and Shani, 1989; McKelvey, 1994; Meenaghan, 1994; McDaniel and Kinney, 1998; Crompton, 2004; Pechtl, 2007). Others examine the ethical aspects (see Ettorre, 1993; Meenaghan, 1994; Pound, 1996; Doust, 1997; Payne, 1998; O’Sullivan 
and Murphy, 1998) and legal aspects (see Townley et al., 1998; Hoek and Gendall, 2002; Crow and Hoek, 2003) of the issue. Of note, the range of scientific $v s$ editorial publications seems to create some confusion as to what ambush marketing really means. Hoek and Gendall (2002) and Crow and Hoek (2003) suggest that considerable vagueness surrounds the concept of ambush marketing. On the one hand, the IOC sees ambush marketing as 'stealing' something from the sponsor and as being 'non-creative, non-ethical and non-professional. Corporations that feel forced to sink to this level should fire their marketing people and look for a new advertising agency' (Pound, 1996: 1). Others (Shani and Sandler, 1998) suggest that it is not realistic to expect non-official sponsors to treat sponsorship in a manner that differs from other competitive promotional techniques and therefore such action cannot be considered as unethical. This is supported by Hoek and Gendall (2002) and Crow and Hoek (2003), who suggest that most discussions around ambush marketing include normal competitive practices. Thus, ambush marketing can be construed as a legitimate competitive marketing practice (Hoek and Gendall, 2002).

Many studies focus on consumer reactions and attitudes towards ambush marketing. The results are not consistent, probably due to different samples gathered from different countries and events (Sandler and Shani, 1989, 1993; Stotlar, 1993; Graham, 1994; McDaniel and Kinney, 1996, 1998; IOC, 1997; Shani and Sandler, 1998; Lyberger and McCarthy, 2001; Preuss, 2004; Séguin et al., 2005). However, they are consistent on a few findings: (i) ambush marketing does create confusion among consumers; (ii) consumers are not aware of the issue; and (iii) consumers do not really care about the issue. The point regarding consumer confusion is of concern, as it implies some degree of clutter in the marketplace.

\section{The Character of Ambush Marketing}

The concept of product 'exclusivity' in the context of Olympic Games sponsorship was introduced at the 1984 Olympic Games in Los Angeles. Prior to that time, sponsorship was offered to all corporations willing to pay for the rights. For example, a total of 628 companies signed sponsorship agreements with the 1976 Olympic Games in Montreal, totalling \$20 million in value (Landry and Yerlès, 1996). The decision to offer product exclusivity by the organizers of the 1984 Games meant fewer companies could associate with the Games (35 companies became sponsors) and affected revenue, which reached \$157 million (LAOGOC, 1985). Following the financial success of the Los Angeles Olympics, the IOC created TOP by offering large multinational companies worldwide exclusivity. This 'exclusivity' led to fierce 
battles among some of the world's most powerful brands, that is, between American Express (non-sponsor) and VISA (TOP-sponsor) being quite notorious. American Express was accused several times of using misleading advertising and ambush marketing tactics against the Olympic sponsor VISA between 1992 and 1994, but responded by suggesting that the goal was not to deliberately employ ambush marketing, but to react to VISA commercials implying that only VISA cards could be used for payments at the Olympic Games. Interestingly, American Express decided to refrain from misleading commercials during the 1996 Olympic Games in Atlanta (Netzle, 1996; Schlossberg, 1996).

While a number of authors have described various techniques of ambush marketing (Meenaghan, 1994; Crompton, 2004), we suggest that the most common purposes of ambush marketing are

1. to benefit from the image of being a sponsor without paying for it,

2. to counterbalance the Olympic commitment of market competitors,

3. to correct 'misleading' campaigns of sponsors,

4. to benefit from Olympic Games if sponsorship rights are too expensive or the category is blocked,

5. to benefit by saving the money that would have been spent for the sponsoring rights in order to spend it on advertisements.

Investigations by Sandler and Shani (1993) indicate that ambush marketing is only worthwhile if the ambush marketer advertises more and in a more creative way than the official sponsor.

Besides the many incentives for ambush, there are also other reasons that oblige corporations to use ambush marketing as a strategy. The following are possible motives for Chinese corporations to engage in ambush marketing campaigns during the television coverage of the Athens Olympics in 2004 and with the exception of the first reason might also serve to instigate ambush marketing activities during the Beijing Olympics.

1. Category exclusivity: Only one company in a given product category can sponsor the Olympics. Hence, ambush marketing becomes a valuable strategy for those wishing to create association with the Olympics (Drengner and Sachse, 2005: 1).

2. High price: The price of Olympic sponsorship is too expensive for smaller corporations to consider official sponsorship (Séguin, 2002).

3. Restricted advertising space: Beginning in Athens, the IOC and the OCOG have exclusive marketing rights at public advertising spaces over the entire host city. All advertising spaces within the city are reserved for Olympic sponsors during the Games. A similar tendency can be observed with TV rights holders, which offer first right of refusal on all advertising inventory. 
This reduces the possibility for non-sponsors to gain a share of consumer attention and may lead to ambush.

In addition, it is suggested that consumers have a lack of knowledge (Bruhn and Ahlers, 2003: 276) when it comes to ambush marketing. This is supported by a three-country study (Canada, USA, Germany) conducted during the 2004 Athens Olympics (McCarthy et al., 2005), proving that 59.8 per cent of Americans (36.2 per cent Canadians/54.5 per cent Germans) believe that the Olympic Rings can be used by all corporations, not just official sponsors. This lack of knowledge is perhaps higher in the PRC if one considers that its economy is still influenced by the former Soviet-style centrally planned economy. In particular, smaller corporations may not have the expertise to fully take advantage of a sponsorship and may not even be aware that sport sponsorship is a protected intellectual property in China. This is not exclusive to China. For example, the German NOC has sent written notice to approximately 425 companies believed to have engaged in ambush marketing activities since 2004. Most corporations stopped upon receipt of the first written notice and only one case proceeded to legal action. ${ }^{1}$

There is some evidence that corporate awareness increases through the use of ambush marketing (Preuss, 2004: 158). If one considers that as many as 34 per cent of American consumers prefer the products of Olympic sponsors, or whoever they regard as being one, ambush marketing can indeed pay off (Schlossberg, 1996). In addition, the results of the three-country study indicate highly significant results that, as consumers' interest in the Olympics increases, so does their buying intention towards Olympic sponsors' products. According to Netzle (1996: 86) ambush marketing strategies are not taken seriously by consumers and as a result may be a fairly 'safe' way to gain some benefit from associating with an event like the Olympics: 'The subtle hints [of the ambush marketer] frequently cause smiles and a certain liking for the advertising corporation. The general public considers ambush marketing rather a trivial offence, to be tolerated'. However, Séguin et al. (2005) suggest that the perception and attitude of the public towards ambush marketing issues may differ according to nationality. Bruhn and Ahlers (2003) mention that ongoing commercialization and ever more rigid trademark rights of events organizers increases the acceptance of ambush marketing in public opinion. Empirical data from the three-country study shows that 51.2 per cent of Germans either 'strongly agreed' or 'agreed' that those 'using an Olympic message without paying the rights fee [...] are employing clever marketing tactics', compared to 44.2 per cent in Canada and 36.3 per cent in the USA. Such data are not yet available for the PRC. Nevertheless, given the lack of importance generally given to international property rights (IPR) in China, it can be assumed that ambush marketing may be viewed as a shrewd marketing tactic. 
Other studies also examine public opinion of ambush marketing. When respondents were asked if they have a 'lower opinion of companies practising ambush marketing techniques', Sandler and Shani (1993) report that 20 per cent agreed. On the other hand, Sponsorship Research International reports that 68 per cent of Americans would agree (IOC, 1996). More recently, Séguin et al. (2005) indicate that nearly 50 per cent of respondents have a lower opinion of companies who practice ambush marketing. However, they report significant differences between Canadians (63 per cent), French (40 per cent) and Americans (42 per cent) (Séguin et al., 2005). Hence, it is suggested here that there may be potential brand risks (image, values, etc.) for companies using ambush marketing techniques. These risks increase when examined in light of purchase behaviour. Empirical data from the three-country study show that 28.0 per cent of Americans, 36.2 per cent of Canadians and 24 per cent of Germans would be less likely to purchase products from companies that 'use an Olympic message without paying for the rights fee'. Here, so-called 'education and shaming' strategies may be successful in fighting ambushing (Pechtl, 2007: 54-55); such strategies should take into consideration national differences in attitudes towards ambush marketing (Séguin et al., 2005).

\section{Steps Taken to Prevent Ambush Marketing}

Over the years, NOC and OCOG defence mechanisms against ambush marketing have ranged from warnings (eg legal letters) to public relations techniques (eg public shame) to public trials. In the case of a NOC, it can take legal action on its own, since it has a mandate to protect the Olympic Rings in its own country. For OCOG, legal action may be taken when there is a misuse of the emblems or a protected symbol (ie for Games purposes). Legal steps can also be taken by the IOC if there are definite legal infringements. The situation is more difficult if ambush marketers do not use the protected words, symbol or other emblems (Schlossberg, 1996) and ambushers are getting much more sophisticated in their use of ambush marketing. Farrelly et al. (2005: 342) interviewed 20 marketing professionals in 2005 and found that ambushers can 'create a false association between an event and their product or brand (...) without infringing or breaching trademark or intellectual property laws'. Hence, while ambush marketing is difficult to manage, there are a number of responsibilities that both the IOC and its partners (NOCs, OCOCs and sponsors) must assume in dealing with this issue (Séguin and O'Reilly, 2008). They suggest that the most effective way for the IOC to manage ambush marketing is to develop a brand management system. This includes: an integrated public relations plan; a team of 'brand masters'; an integrated marketing/communication programme of sponsors; close working relationships between partners; and an education programme. 
The IOC and OCOG have used PR activities such as press conferences and press releases to sensitize the public to ambush marketing. There was the case of the Vancouver Organising Committee for the 2010 Winter Olympics (VANOC), a few months prior to the 2006 Olympic Winter Games in Turin. VANOC publicly condemned the promotion of a well-known oil company through an aggressive public/media relations campaign using a high-profile Olympian as a spokesperson. The company was described as engaging in 'unethical' behaviour (ie ambush marketing) damaging to VANOC's future potential to secure sponsorship agreements. They argued that such activities could lead to fewer dollars going to Canadian athletes (ie stealing from athletes) and jeopardize VANOC's revenue potential. The wide media coverage of this case led the oil company to refocus its promotional strategy and terminate its campaign (Hotzau, 2007). In turn, this gave VANOC's official sponsor, Petro-Canada, a clean marketplace in which to conduct its Olympic promotions.

While such a strategy was successful in Canada, it may not be in other countries (Séguin et al., 2005). Hence, additional protection may be provided in the form of legislation. This is the case in the PRC, whose Olympics IPR protection is believed to be an 'essential element to ensure a successful Games' (Wang Youpeng, Director of the Beijing Municipal Bureau of Intellectual Property, 2001. http://english.peopledaily.com.cn/english/200111/ 01/eng20011101_83679.html; accd. 7 December 2007).

To protect the intellectual property of the IOC, Olympic Charter §14 (Byelaw 1.2) states:

Each NOC is responsible to the IOC for the observance, in its country, of Rules 7-14 and BLR7-14. It shall take steps to prohibit any use of any Olympic properties which would be contrary to such Rules or their Byelaws. It shall also endeavour to obtain, for the benefit of the IOC, protection of the Olympic properties of the IOC. (IOC, 2004)

In order to safeguard the interests of Olympic sponsors and fulfil the Olympic Charter, as part of the Host City Contract, the 54th Executive Meeting of the State Council of the PRC adopted on 30 January 2002 the Olympic Symbol Protection Law, effective as of 1 April 2002 (http://www.ipr.gov.cn/ipr/en/info/ Article.jsp?a_no $=2168 \&$ col_no $=119 \& d i r=200603$; accd. 1 November 2007). The regulations were formulated to strengthen the protection of Olympic symbols, safeguarding the lawful rights and interests of the rights-holders of Olympic symbols and maintaining the dignity of the Olympic Movement.

Article 2 (Olympic Symbols Protection Law) defines Olympic symbols as referring to:

(1) The five Olympic rings, Olympic flag, Olympic motto, Olympic emblem and Olympic anthem of the IOC. 
(2) Expressions such as Olympic, Olympiad, Olympic Games and their abbreviations.

(3) The name, emblem and symbols of the Chinese Olympic Committee.

(4) The name, emblem and symbols of Beijing 2008 Olympic Games Bid Committee.

(5) Symbols such as the name and emblem of Beijing Organising Committee for the Games of the XXIX Olympiad, the mascots, anthem and slogan of the 29th Olympic Games, 'Beijing 2008', the 29th Olympic Games and its abbreviations.

(6) Other symbols related to the 29th Olympic Games laid down in the Olympic Charter and the Host City Contract for the Games of the XXIX Olympiad in the Year 2008.

Article 3 regulates that the 'rights-holders of Olympic symbols' refers to the IOC, the Chinese Olympic Committee (COC) and the Beijing Organising Committee for the Games of the XXIX Olympiad. Article 4 then regulates who is allowed to legally use Olympic symbols for commercial purposes: 'No one may use Olympic symbols for commercial purposes (including potential commercial purposes, [...]) without the authorisation of the rights-holders'. For the purpose of these regulations, 'use for commercial purposes' means the use of Olympic symbols for profit-making purposes as described in Article 5:

(3) The use of Olympic symbols in advertising, [...]; [...]

(6) Other acts that might mislead people to think there are sponsorship or other supporting relations between the doers and the rights-holders of Olympic symbols.

\section{IPR in the PRC}

The difficulties in enforcing protection for IPR in the PRC can be found in Hesse's (2002) position on IPR, namely, that the belief that an idea can be owned 'is a child of European Enlightenment'. Hence, it can be argued that, historically, IPR is something of a foreign custom to Chinese culture. Some possible reasons can be advanced for this (see, eg Nippa, 2004: 70-74).

First, it has been argued that China's Confucian traditions have focussed on the transmission of creative work that others can build upon, rather than learning and/or creating anew, as found in individualistic activity (Alford, 1995). The Confucian statement 'I transmit rather than create - I believe in and love the ancients' (cited by Montgomery and Fitzgerald, 2006: 408) is often referred to as an example of this approach. China's communism, where intellectual property viewed as common property offered the greatest benefits to society when used and shared without restriction, did nothing to contradict 
or displace traditional Confucian notions. Furthermore, copying directly from others was to be seen as a compliment to the author, rather than an infringement of his or her 'natural' rights. As a result, free copying from the work of other approved authors and artists was not only tolerated, but encouraged (Alford, 1995).

Second, socialism also supports these ideas. Even if China's Confucian traditions were thoroughly interrupted by the political and ideological end of the Qing dynasty, the Communist Party of China's approach to intellectual property after 1949 (which emphasizes society's need to access material rather than an author's right to profit from his creations) did not represent a radical break from Chinese traditions of sharing and copying $(\mathrm{Qu}, 2002)$. According to Montgomery (2004: 13), 'a number of scholarly authors ... have also argued that the historical absence of copyright law in China means that there has been little opportunity for consciousness of intellectual property issues or rights to develop'. Even though the PRC's Trademark Law, effective 1 March 1983, marked the beginning of a systematic establishment of a modern legal system for IPR protection (see http://www.china.org.cn/e-white/intellectual/12-2.htm; accd. 1 November 2007), in the opinion of many authors the situation did not change: 'Formal copyright law and the development of a court system did not become significant factors in China's intellectual property environment until the 1990s' (Montgomery, 2004: 12). The development of intellectual property concepts still tends to fall behind technological progress, making the intellectual property law unspecific for guiding intellectual property activities (Wagman and Scofield, 1999; Maskus, 2000) and leaving too much unexplained (Teece, 1986). Sometimes, too, local protectionism may dilute the strength of central legislation or the power of law enforcement.

Moreover, as mentioned above, the court system for the protection of IPR has only been established for 20 years in China; lawyers and judges need more time to build experience and expertise. As a result, uniformity of judicial decisions may be undermined in the process of dispute settlement. Qu (2002) summarizes this when she says it has also been widely observed that one reason for failure to deal with copyright issues in the courts is a serious shortage of judges familiar with copyright theory and its application.

But a thorough grasp on handling issues related to intellectual property is not only missing in the courts, but in the day-to-day realities of companies and consumers who believe that they are doing nothing wrong in copying from others. Montgomery (2004: 12) cites Wang Shi, director of the Chinese Culture Promotion Society: 'in China, piracy is very popular'. And, describing the situation on the film market, she remarks 'most consumers of pirated film products in China have little sense that piracy has any impact on the production of film'.

Without an education strategy on IPR, it is difficult to raise awareness in the PRC that infringement is illegal. For example, the fact that the official Olympic 
broadcaster CCTV5 was illegally using the Olympic Rings in TV commercials illustrates that the protection of official sponsors was less important than promoting the Olympic engagement of the TV channel.

Nevertheless, it is often claimed that there is growing interest in protecting IPR, because the PRC is facing increasing problems the more they trade with Western society. This is particularly true for sports marketing rights.

However, in reforming domestic laws and practices in order to satisfy obligations included in documents such as the Agreement on Trade Related Aspects of Intellectual Property (TRIPs), Chinese policymakers should not forget the way in which cultural products have been shared and incorporated as cultural practice in the absence of strict intellectual property laws in the past. These principles of 'opening' information are becoming an important aspect of IP systems in the West.! (Montgomery and Fitzgerald, 2006: 408)

It can be argued that publicly sharing Olympic symbols could benefit the Olympic Movement. In such a case, corporations could use Olympic symbols and educate consumers on Olympic matters without cost. For non-commercial purposes particularly, the free use of symbols could be (and is already partly) allowed. Hence, if Olympic symbols associations and values were seen as cultural goods, rather than commercial interests, IPR legislation would be unnecessary.

However, for the purpose of financing the Olympic Movement it is essential to protect sponsors. China may have much to gain by incorporating its own scholarly traditions and historical experiences within the intellectual property system in sports rights, which it is now committed to develop. Hence, this study seeks to investigate the perception and use of ambush marketing on the Chinese public television network CCTV5 by examining commercials used by various corporations during the coverage of the 2004 Athens Olympics.

\section{Methodology}

Despite the guarantees given by the Chinese government, doubts remain over whether the fight against ambush marketing ahead of and during the Beijing Olympic Games can be successful in China. The opportunities for ambush are manifold, as categorized by Crompton (2004: 2)

1. Sponsorship of an event broadcast.

2. Purchase of advertising time in and around event broadcasts.

3. Sponsoring of entities other than the organizing body.

4. Purchasing advertising space in locations close to the event venue.

5. Thematic advertising and implied allusion. 
6. Creation of a counter-attraction.

7. Accidental ambushing.

The empirical part of this paper focuses on ambush marketing shown on CCTV5 during the Olympic Games in Athens in 2004. Only cases using Crompton's technique 2 , in combination with points 3 or 5 , were considered. Live coverage was used to determine whether non-sponsors used themes, symbols, images or persons associated with the Olympics, which would fulfil the criteria for thematic advertising. Each commercial was analysed using a five-category list developed by the authors (see Table 2).

In order to address the research objectives of providing insights on ambush marketing in PRC ahead of its hosting the Olympic Games, data were collected from three sources: (i) TV-commercial recordings in China during broadcasts of the 2004 Athens Olympics, (ii) TV commercials from nine other countries and (iii) qualitative data about the particular sponsorship situation in China

Table 2 Categorization of Olympic ambush marketing

\begin{tabular}{|c|c|c|}
\hline Category of ambush & Description and examples & $\begin{array}{l}\text { Number of } \\
\text { category by } \\
\text { Crompton }\end{array}$ \\
\hline $\begin{array}{l}\text { Type 1: Direct ambush } \\
\text { marketing - using pro- } \\
\text { tected symbols (China's } \\
\text { Olympic Symbol Protec- } \\
\text { tion Law (Art. 2) or IOC } \\
\text { Charter } § 14)\end{array}$ & $\begin{array}{l}\text { Olympic Rings, Olympic Emblem of OCOG } \\
\text { or NOC, Word 'Olympic', Olympic Hymn, } \\
\text { Olympic Flame, Olympic Motto, Olympic } \\
\text { anthem, Olympic Mascot or slight amend- } \\
\text { ments thereof }\end{array}$ & 2 and 5 \\
\hline $\begin{array}{l}\text { Type 2: Indirect ambush } \\
\text { marketing: Strong viola- } \\
\text { tion of } \$ 14 \text { IOC Charter }\end{array}$ & $\begin{array}{l}\text { As Type } 1 \text {, but more abstract with regard to } \\
\text { Hymn, Fire and Motto. 'Any visual or audio } \\
\text { representation of any association, connection } \\
\text { or other link with the Olympic Games, the } \\
\text { Olympic Movement or any continuant there- } \\
\text { of' }\end{array}$ & 2 and 5 \\
\hline $\begin{array}{l}\text { Type 3: Indirect ambush } \\
\text { marketing: Light viola- } \\
\text { tion of } \$ 14 \text { IOC Charter }\end{array}$ & $\begin{array}{l}\text { As Type } 2 \text {, but in very abstract form, using } \\
\text { sports symbolism related to Olympic Games } \\
\text { (eg stadiums, medals and victory ceremonies) }\end{array}$ & 2 and 5 \\
\hline $\begin{array}{l}\text { Type 4: Violation with } \\
\text { regard to time or cate- } \\
\text { gory }\end{array}$ & $\begin{array}{l}\text { Sponsors of past or next Games who start } \\
\text { using their rights at a wrong time or sponsors } \\
\text { that use rights that are not in their product } \\
\text { categories or at their sponsor level }\end{array}$ & $\begin{array}{l}2 \text { and } 3 \\
\text { and/or } 5\end{array}$ \\
\hline $\begin{array}{l}\text { Type 5: Persons and } \\
\text { congratulations }\end{array}$ & $\begin{array}{l}\text { Athletes and coaches, seen during the Games } \\
\text { in a commercial or congratulations (w/o } \\
\text { acceptance by the IOC executive board) }\end{array}$ & 2 and 3 \\
\hline
\end{tabular}


during Athens 2004 (eg interview with an IOC marketing manager; Olympic Charter; Chinese Olympic Symbol Protection Law).

On 26 and 27 August 2004, 16 hours of TV broadcasts were recorded in 10 countries. Every day between 2 p.m. and 10 p.m. local time, broadcasts of the rights-holding TV channel were recorded, regardless of content. The countries involved were Argentina, Australia, Brazil, China, Germany, Estonia, France, Netherlands, Switzerland and Spain. Additionally 'Eurosport' (European sports channel) coverage was recorded in Germany (as such, the commercials were in German), covering the same period as above.

The data collected for this research consisted of two components. The first is an analysis of 40 commercials (during 10-minute commercial breaks) on CCTV5 in the PRC. The commercials were shown on 26 August 2004, during the Olympic broadcast. A Professor in Chinese language at Johannes Gutenberg University in Mainz translated the spoken and written Chinese into German. A second check of commercials from Jinlaike and translation into English was done by an expert researcher in Anthropology from the University of Missouri in the USA. ${ }^{2}$ The analysis considered spoken and written words and the interpretation of visual as well as acoustic elements. The focus was placed on violations of the regulations regarding Olympic Symbol Protection, as categorized in Table 2. In 2004, only the official Olympic sponsors of the COC (six partners, five TOP sponsors and six sponsors) and the IOC TOP sponsors (10 corporations) had commercial rights for PRC territory. In cases where other corporations sought to associate themselves as Olympic sponsors or violated the Olympic Charter, these were considered potential ambush marketing. A deeper internet analysis of the corporations clarified any relationship to the Olympic Movement. In unclear cases, such as corporations related to the Olympic Movement but not an official sponsor, the IOC Marketing department was contacted in order to unfold exclusionary rules. It is worth noting that the IOC executive board or other appropriate members of the IOC Marketing commission may allow the use of protected symbols or the involvement of Olympic athletes in commercials on a case-bycase basis. However, the IOC was not willing to provide a clear answer in all cases, for reasons of confidentiality. Two requests to the general secretary of the COC went unanswered. In order to avoid misinterpretation, the empirical results shown here should not be taken as precise figures, but as tendency. The results demonstrate a clear and significant statement.

The second part of the analysis addresses all countries and commercial breaks during the 16 hours of coverage recorded. Note that the countries selected were part of a larger research project by the authors. Hence, the choice of countries traditionally exposed to Confucianism and/or more comparable to China in terms of development and IPR protection were not part of this sample. For the purpose of this research, only a quantitative analysis 
(frequency count) of ambush advertisements was processed. Owing to language barriers and the huge amount of data (176 hours of recordings), only a rough visual interpretation could be carried out. Commercials were categorized as ambush marketing when corporations other than NOC and TOP-sponsors used Olympic symbols or a clear Olympic or Greek association. This limitation on visuals probably underestimates the true number of ambush attempts. The quantitative analysis was processed by Berzel (2005). In order to count ambush attempts, researchers had to interpret the commercials. The issue of bias in qualitative research is important, and demands special attention. Here, the same person worked on the interpretation of all commercials. Potential misinterpretations do not affect the general outcome of the research, because the same mistake would occur in each country.

\section{Results}

First, an analysis of 40 commercials on CCTV5 was undertaken. No Type 1 violation was found. Therefore, the COC could not initiate legal action against any corporation. However, several cases of Types $2-5$ of ambush marketing were identified.

Due to four commercials violating two categories (Table 2), the 40 analysed commercials total 44 cases in Table 3 . In all, more than 35 per cent of the commercials were found to infringe China's Olympic Symbol Protection Law. This confirms the immense interest of Chinese corporations to be connected to the Olympic Games. This will be examined in more depth by using two case studies. Both cases are private corporations in the sports shoes and sportswear sector. The official sponsor of the COC for the sportswear category was Beijing Li-Ning Sports Goods Co. Ltd. (see http://www.li-ning.com.cn/ for a company profile; accd. 10 December 2007).

Table 3 Categorization of 40 TV-commercials from CCTV5

Category of ambush/sponsorship

Number of

cases

Type 1: Direct ambush marketing — using protected symbols (China's Olympic 0

Symbol Protection Law (Art. 2) or IOC Charter \$14)

Type 2: Indirect ambush marketing: Strong violation of $\$ 14$ IOC Charter 2

Type 3: Indirect ambush marketing: Light violation of \$14 IOC Charter 9

Type 4: Violation in regards to time or category 3

Type 5: Persons and congratulations 3

No violation $\quad 19$

TOP sponsor $\quad 2$

$\begin{array}{ll}\text { National sponsor (COC) } & 4\end{array}$

Total

44 


\section{Case 1: Anta}

Anta produces sports products and was neither a sponsor of the COC nor a TOP sponsor in 2004. However, it does have an Olympic connection, in that it dressed the Chinese Olympic Team in Sydney 2000 and was also a sponsor of the Beijing Olympic Bid campaign until 2001. Anta was founded in 1984 and has become one of the biggest comprehensive sports equipment providers in China. It calls itself the 'pioneer of China's sports marketing and supporter of China's sports cause' (http://www.anta.com.cn/eng/about/profile.htm; accd. 10 December 2007) and is a good example of employing Olympic imagery without recourse to protected symbols. The 15-second commercial analysed here included:

- An ancient Greek temple, creating a direct association to the Athens Olympic Games.

- Fire (several times in this commercial). This relates to the Olympic flame, though neither a torch nor the Olympic cauldron was used.

- Famous Chinese table-tennis player Wang Hao, a silver medallist at the 2004 Athens Olympics. He appears several times in the commercial with his face clearly identifiable, during Olympic competition; a monochrome movie shows his emotions, linked to the Olympic motto 'striving for excellence'. He won his Olympic medal on 23 August and was closely linked to the Olympics at the time of the broadcast.

- A statue of the Greek discus thrower (Discobolus), a famous Olympic statue sculpted by Myron in around 460 BC, exemplifying the Greek sense of harmony and balance (Rhythmos) and directly related to the Olympic Games in Athens.

- An athletic modern discus thrower. This brings the associations back to the actual high-performance sport.

- The acoustic accompaniment is glorificatory instrumental music, similar to Vangelis' 'Chariots of Fire'. Vangelis produced the theme music for the Winter Olympics in Sarajevo in 1984 and the theme has often been used since for documentaries about the Olympic Games.

Owing to this content, this commercial can be classified as Type 2 ambush (Table 3).

\section{Case 2: Jinlaike}

Jinlaike Sporting Goods Company, Ltd is a private corporation specializing in producing and selling sports goods. The 15-second commercial analysed here featured:

- Fire and the corporation's 'Jinlaike' flag. This directly evoked an association with the Olympic Games, although no Olympic torch, nor cauldron, nor flag was used. 
- The introductory audio track was the excited cheering of thousands of spectators in a big stadium, continuing with a small group of fans cheering on Athens 2004 table-tennis gold medallist, Wang Nan. The spectators yell: 'Go, go, Wang Nan, go! Go, Wang Nan, go, go!' Finally come wild cheers after a successful table-tennis spike; such sounds underpin the association with sports and sporting events.

- The strongest violation was a direct reference to Athens, by a speaker saying that 'Believe in yourself. Jinlaike ignites the passion of Athens'.

Due to this content this commercial can also be classified as Type 2 ambush (Table 3).

In both cases, 2004 Olympic medallists were used as testimonials in the commercials and the Olympic Rings were displayed during non-sponsor commercials.

Unless given prior permission from the IOC Executive Board, the testimonials of Wang Hao, 2004 Olympic silver medallist, and Wang Nan, 2004 Olympic gold medallist, violated Olympic Charter Rule \$41 (Bye-law 3). Such permission, moreover, is unlikely, as Anta and Jinlaike were not official sponsors.

Except as permitted by the IOC Executive Board, no competitor, coach, trainer or official who participates in the Olympic Games may allow his person, name, picture or sports performances to be used for advertising purposes during the Olympic Games. (IOC, 2004)

The limitation of media exposure by Olympic athletes is even further limited by Rule $\$ 51$ (Bye-law 3).

Under no circumstances, throughout the duration of the Olympic Games, may any athlete, coach, official, press attaché or any other accredited participant act as a journalist or in any other media capacity. (IOC, 2004)

In other words, it is not permissible for an Olympic athlete to appear in a TV commercial during the Olympic Games. In cases of infringement, the IOC (2004) may follow $\$ 53$ (Bye-law 1.6) "Any violation [...] shall result in disqualification or withdrawal of the accreditation of the person concerned'. This type of ambushing is classified as Type 5 in Table 2 .

Concerning the visibility of the Olympic Rings in all TV commercials, additional confusion was created about who was sponsoring the Olympic Games. CCTV5 displayed the combined logo of its channel and the Olympic Rings during the entire commercial break in the top left corner of the screen. The Olympic Charter Rule 7-14 (Bye-law 2.3) states:

The IOC, at its sole discretion, may authorise the broadcasters of the

Olympic Games to use the Olympic symbol, the Olympic emblems of the 
IOC or other Olympic properties of the IOC and the OCOGs to promote the broadcasts of the Olympic Games. (IOC, 2004)

This does not include the misleading presentation of the Olympic Rings during commercials of non-sponsors, as Benjamin Seeley, IOC Marketing Communications Manager, confirmed:

the right for broadcasters to use the Olympic logo or their composite Olympic logo during commercial breaks is not granted, as the use of marks should be directly used in connection with the broadcast of the Games and the promotion of the coverage of the Olympic Games. (Document received 27/8/2007)

Despite the power of the IOC to immediately disconnect an accredited TV station not following the rules of the Olympic Charter, the IOC did not switch off CCTV5 from Olympic coverage. Perhaps the consequences of disconnecting a potential audience of more than 1 billion viewers from Olympic coverage were enough to deter such actions. Since CCTV is the only available TV partner for the IOC in China, action against the channel is even less likely. It remains unclear if CCTV knew about its violation and/or if the IOC was aware of CCTV's infringement.

When compared to other countries it is clear that China is prone to ambush marketing. The reasons for this have been discussed above. The comparison made herein was to show the existence of ambush marketing in other countries. TV recordings from countries similar to PRC were not available.

The analysis presented in Figure 1 is based on the visual interpretation of the commercials. Here only the ratio of violations between the various countries is of importance. The analysis confirms the unspoken apprehension that the Chinese market offers fertile ground for corporations seeking ambush opportunities. However, one must recognize that the benefits associated with Olympic sponsorship go well beyond public attention.

In comparison to the deep analysis of the 40 spots (with 35 per cent ambushing), the 16.6 per cent ambush spots in Figure 1 are a rather conservative result. The reason is that in some cases ambush appears only in the spoken words, through the use of testimonials (unknown by the interpreter), while in other cases they were Type 3 ambush marketing, which were not considered for this study (Table 2).

\section{Conclusion}

In comparison to Western and other developed countries, the PRC, for several reasons, appears to be a country prone to ambush marketing. We suggest that it is a mix of the reasons presented throughout this paper, and summarized 


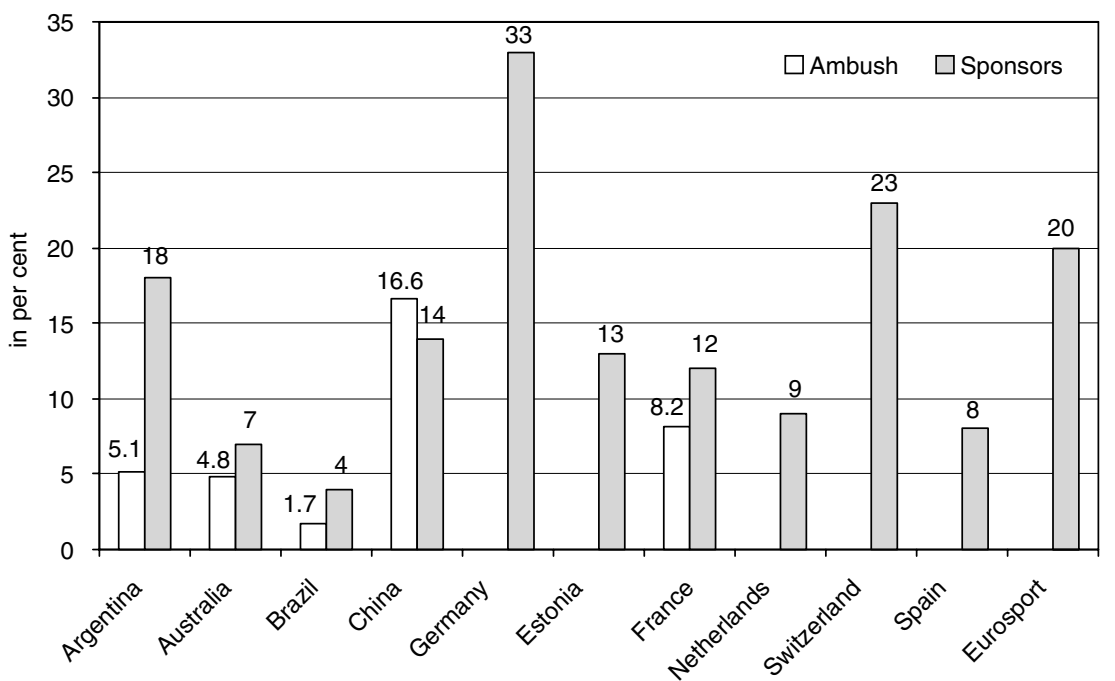

Figure 1 Sponsor and ambush commercials during 16 hours of TV broadcast in 10 countries (per cent). Source: Berzel (2005).

below, that may explain this situation. Further research could examine whether these might also apply to countries similar to China.

1. The Chinese tendency to copy is based on Confucian tradition.

2. The people of PRC are socialized in communism, holding in particular to the assumption that everything belongs to everyone.

3. Low understanding exists of sports sponsorship rights in a competitive market economy where the IPR of sports organizations are protected.

4. economic education of both managers (from non-sponsors) and consumers is limited. In part this is based on a low level of 'education and shaming' strategies.

5. poor jurisdiction ( $\mathrm{Qu}, 2002)$, in particular to laws that need interpretation, exists.

In order to protect the Olympic brand and increase the value of Olympic sponsorships, the IOC will have to ensure compliance with the Olympic Symbol Protection Law in the PRC. If ambush marketing is left unchecked, then the fundamental revenue base of sport will be undermined.

On numerous occasions, the Beijing Organising Committee of the Olympic Games 2008 stressed the importance of IPR protection as a fundamental target. Considering (i) that Beijing was selected as host city in 2001 and (ii) that the Olympic Symbol Protection Law was in force as early as 2002, the 
empirical results of this paper raise doubts as to the success of this ambitious target.

The future of Olympic sponsorship depends on the ability of the Olympic Movement to maintain the Olympic aura and the exclusiveness of the sponsors. Furthermore, the IOC must strengthen the value of sponsorships and the Olympic brand by controlling the number of visible sponsors. With its longterm orientation, the IOC must effectively protect its partners against ambush marketing (Florin and Carlin, 1995). However, this will remain a challenge, since legal means can only be applied for categories 2, 4 and 5 listed in Table 2.

The world is looking to China. From a business standpoint, the Games provide an opportunity to further develop economic and trade relationships with the country. One focus of attention will be on serious discussion and action on IPR protection. Future investigations will show if the fight against ambush marketing has been successful or not.

\section{Note}

1 Personal interview with Thomas Arnold, German NOC Director of Finance, 14 September 2007.

2 Thanks for interpretation to Prof. Dr. Andreas Guder (University of Mainz, GER) and Prof. Dr.

Susan Brownell (University of Missouri, USA).

\section{References}

Alford, W.P. (1995) To Steal a Book is an Elegant Offence: Intellectual Property Law in Chinese Civilization, Stanford: Stanford University Press.

Berzel, C. (2005) 'Die Präsentation der Olympischen Spiele von Athen 2004 in der Fernsehwerbung - ein internationaler Vergleich', Unpublished Masters Thesis, Institute of Sports Science, Johannes Gutenberg University, Mainz.

Bruhn, M. and Ahlers, M. (2003) 'Ambush-marketing - 'attack from behind", Yearbook of Marketing and Consumer Research 2(1): 40-61.

Crompton, J.L. (2004) 'Sponsorship ambushing in sport', Managing Leisure 9(1): 1-12.

Crow, D. and Hoek, J. (2003) 'Ambush marketing: a critical review and some practical advice', Marketing Bulletin 14(1): 1-14.

Doust, D. (1997) 'The ethics of ambush marketing', Cyber-Journal of Sport Marketing 1(3). Retrieved 21 February 1999 from www.cad.gu.edu.au/cjsm/doust.html.

Drengner, J. and Sachse, M. (2005) 'Die Wirkungen von Ambush Marketing: Ausgewählte Ergebnisse einer empirischen Untersuchung anlässlich der Fußball-Europameisterschaft 2004', in H.D. Horch, G. Hovemann, S. Kaiser and K. Viebahn (eds.) Perspektiven des Sportmarketing: Besonderheiten, Herausforderungen, Tendenzen - Beiträge des 4. Deutschen Sportökonomie-Kongresses, Köln: Institute for Sporteconomy and Sportmanagement, pp. 71-87.

Ettorre, B. (1993) 'Ambush marketing: heading them off at the pass', Management Review 82(3): 53-57.

Farrelly, F., Quester, P. and Greyser, S.A. (2005) 'Defending the co-branding benefits of sponsorship B2B partnerships: the case of ambush marketing', Journal of Advertising Research 45(3): 339-348. 
Florin, K. and Carlin, D. (1995) 'Ambush protection for Olympic sponsors', Advertising Age 66(44): 22-24.

Graham, P.J. (1994) 'Ambush marketing: an American perspective', Third Annual Conference on Sports Marketing Law, Tax and Finance; September 1994; Lausanne, Switzerland.

Hesse, C. (2002) 'The rise of intellectual property, 700 B.C.-A.D. 2000: an idea in the balance', Daedalus 131(2): 26-45.

Hoek, J. and Gendall, P. (2002) 'Ambush marketing: more than just a commercial irritant?', Entertainment Law 1(2): 72-91.

Hotzau, A. (2007) 'Ambush Marketing: principles, stakes, creativity, applications', Intelligence Report 1(1): 1-19.

International Olympic Committee (1996) Marketing Fact File 1996, Lausanne: IOC.

International Olympic Committee (1997) Olympic Market Research Analysis Report, Lausanne: IOC.

International Olympic Committee (2004) Olympic Charter, Lausanne: IOC.

International Olympic Committee (2006) Marketing Fact File 2006, Lausanne: IOC.

Landry, F. and Yerlès, M. (1996) The Presidencies of Lord Killanin and Juan Antonio Samaranch, Lausanne: IOC.

LAOGOC (Los Angeles Olympic Games Organizing Committee) (1985) Official Report of the Games of the XXIIIrd Olympiad Los Angeles, 1984, Los Angeles: LAOGOC.

Lyberger, M.R. and McCarthy, L. (2001) 'An assessment of consumer knowledge of, interest in, and perceptions of ambush marketing strategies', Sport Marketing Quarterly 10(3): 130-137.

Maskus, K.E. (2000) 'Lessons from studying the international economics of intellectual property rights', Vanderbilt Law Review 53(6): 2219-2240.

McCarthy, L., Seguin, B., Lyberger, M.R., O'Reilly, N. and Preuss, H. (2005) 'Consumer interest, awareness and intent to purchase: a three-country study of Olympic sponsorship', 13th European Congress of Sport Management, Newcastle-Gateshead, UK, 10 September.

McDaniel, S.R. and Kinney, L. (1996) 'Ambush marketing revisited: an experimental study of perceived sponsorship effects on brand awareness, attitude towards the brand and purchase intention', Journal of Promotion Management 3(1/2): 141-167.

McDaniel, S.R. and Kinney, L. (1998) 'The implications of recency and gender effects in consumer response to ambush marketing', Psychology \& Marketing 15(4): 385-403.

McKelvey, S. (1994) 'Sans legal restraints, no stopping the brash, creative ambush marketers', Brandweek 35(16): 20.

Meenaghan, T. (1994) 'Ambush marketing — immoral or imaginative practice?', Journal of Advertising Research 34(5): 77-88.

Meenaghan, T. (1996) 'Ambush Marketing-A threat to corporate sponsorship', Sloan Management Review 38(1): 103-113.

Montgomery, L. (2004) 'Troubled waters for the development of China's film industry', Proceedings: Media Technology, Creative Industry and Cultural Significance; Taipei, Taiwan. http://eprints.qut.edu.au/archive/00002821/01/2821.pdf, accd 16 January 2008.

Montgomery, L. and Fitzgerald, B. (2006) 'Copyright and the creative industries in China', International Journal of Cultural Studies 9(3): 407-418.

Netzle, S. (1996) 'Ambush Marketing, die neue unfaire Marketing-Maßnahme im Sport', SpuRt Zeitschrift für Sport und Recht 13(3): 86-87.

Nippa, M. (2004) Markterfolg in China. Erfahrungsberichte und Rahmenbedingungen, Heidelberg: Physica-Verlag.

O'Sullivan, P. and Murphy, P. (1998) 'Ambush marketing: the ethical issues', Psychology \& Marketing 15(4): 349-366.

Payne, M. (1998) 'Ambush Marketing: the undeserved advantage', Psychology \& Marketing 15(4): 323-331. 
Pechtl, H. (2007) Trittbrettfahren bei Sportevents: das Ambush-Marketing Diskussionspapier 01/07, Rechts- und Staatswissenschaftliche Fakultät, Ernst-Moritz-Arndt-Universität Greifswald.

Pound, R.W. (1996) 'Es ist unkreativ, [...]', DSM, Marketing News 1(3): 1.

Preuss, H. (2004) The Economics of Staging the Olympics. A Comparison of the Games 1972-2008, Northampton: Edward Elgar.

Qu, S. (2002) Chinese Copyright Law, Beijing: Foreign Language Press.

Sandler, D.M. and Shani, D. (1989) 'Olympic Sponsorship vs. 'Ambush' marketing: who gets the gold?', Journal of Advertising Research 29(4): 3-14.

Sandler, D.M. and Shani, D. (1993) 'Sponsorship and the Olympic Games: the consumer perspective', Sport Marketing Quarterly 2(3): 38-43.

Schlossberg, H. (1996) Sports Marketing, Malden: Blackwell.

Séguin, B. (2002) 'Olympic sponsorship and ambush marketing: a qualitative study', Report to the International Olympic Committee, Switzerland: Lausanne, available at Olympic Studies Centre Library.

Séguin, B., Lyberger, M., O'Reilly, N. and McCarthy, L. (2005) 'Internationalising ambush marketing - a comparative study', International Journal of Sports Marketing \& Sponsorship 6(4): 216-230.

Séguin, B. and O'Reilly, N. (2008) 'The Olympic brand, ambush marketing and clutter', International Journal of Sports Marketing and Sponsorship 4(1/2): 62-84.

Shani, D. and Sandler, D.M. (1998) 'Ambush marketing: is confusion to blame for the flickering of the flame?', Psychology \& Marketing 15(4): 367-383.

Shank, M. (2005) Sports Marketing: A Strategic Perspective, Upper Saddle River, NJ: Pearson Prentice-Hall.

Stotlar, D.K. (1993) 'Sponsorship and the olympic winter Games', Sport Marketing Quarterly 2(1): 35-43.

Teece, D.J. (1986) 'Profiting from technological innovation: implications for integration, collaboration, licensing and public policy', Research Policy 15(6): 285-305.

Townley, S., Harrington, D. and Couchman, N. (1998) 'The legal and practical prevention of ambush marketing in sports', Psychology \& Marketing 15(4): 333-348.

Wagman, R.G. and Scofield, S.B. (1999) 'The competitive advantage of intellectual property', S.A.M. Advanced Management Journal 64(3): 4-8. 